\title{
Do Brands "JUST DO IT"? Studying the Effectiveness of B2C Slogans
}

\author{
Paulo Duarte Silveira ${ }^{\mathrm{ab} *}$, Susana Galvão ${ }^{\mathrm{a}}$ \\ * Corresponding author: Paulo Duarte Silveira, paulo.silveira@esce.ips.pt \\ ${ }^{a}$ College of Business Administration-Polytechnic Institute of Setúbal, Setúbal, Portugal \\ ${ }^{b} C E F A G E-U E$, Évora, Portugal
}

\begin{abstract}
http://dx.doi.org/10.15405/epsbs.2016.11.02.29

This study aims to contribute to a more effective creation and management of slogans in the context of branding and advertising, testing which factors might influence the brand slogan recall and recognition. An empirical study was conducted, via a self-administered original questionnaire, applied to a sample of 156 elements, analyzing the recall and recognition rates for twenty-nine slogans, from nine different product categories: retailing, cokes, juices, water, sports, telecoms (mobiles), beer, personal care, and ice-cream. The independent variables used to analyze each slogan recall and recognition were: slogan length, slogan antiqueness, brand industry, slogan language, brand consuming frequency and sympathy towards the brand. A positive relationship was found between the antiqueness of slogans and their spontaneous recall. It was also found that the spontaneous recall of slogans has high variation among brands and shorter slogans have higher recall rates. Other variables (slogan language, brand consuming frequency and sympathy towards the brand) did not show a significant impact on the recall/recognition of slogans.
\end{abstract}

(C) 2016 Published by Future Academy www.FutureAcademy.org.uk

Keywords: Slogans; Branding; Positioning; Advertising, Promotion.

\section{Introduction}

Historically, the origin of slogans relate to the host and battle cries used by the Scottish clans, because the word "slogan" is taken from the Gaelic "slaugh-ghairm" (Bauerly \& Tripp, 1997; Aboulian \& McBride, 2007; Figueiredo, 2005). Slogans are a rhetorical device (Denton Jr, 1980) and they usually are a brief expression or phrase, constructed and utilized in marketing, to build or reinforce an image or identity (O'guinn et al. 2011). 
There are several types of slogans. A slogan might be a single word (e.g. 3M - "Innovation") or a phrase including or not the object/brand name (e.g. "Intel inside"). Slogans can be used by an organization (e.g. Red Cross - "The greatest tragedy is indifference"), company (e.g. LG "Life's Good"), brand (e.g. Nike - "Just do it"), product (e.g. Gillette Venus razor - "Reveal the goddess in you"), individual person (e.g. Obama - "Yes We can"), cause (e.g. French revolution - "Liberté, Egalité, Fraternité") or idea (e.g. Jedi - "May the force be with you"). The present study focuses on brand slogans, and they can be defined as "short phrases that communicate descriptive or persuasive information about a brand" (Supphellen \& Nygaardsvik, 2002, p.386). This type of slogan is the one that assists the brand's selling proposition (Dowling \& Kabanoff, 1996).

Although, it is frequently assumed among companies the role of slogans in marketing, Reece et al. (1994) mention that several research studies on slogans aim to provide insights to the discussion if they are more an ornament or if they are a relevant element of the promotion mix.

\section{Problem Statement}

\subsection{Slogan concept and slogan roles within brand management}

In the marketing literature there can be found several definitions for what a slogan is. A recent definition states that a slogan can be defined as a short phrase used to help establish an image, identity, or position for an organization to increase its memorability ( $\mathrm{O}^{\prime}$ guinn et al., 2011). In this stream, and according to Vakratsas and Ambler (1999) model of how advertising works, slogans are an element of the advertising input, since they convey a marketing or branding message.

On the marketing and branding literature there are also many definitions for "brand" (McEnally \& De Chernatony, 1999) and for "brand management" (Louro \& Cunha, 2001; De Chernatony \& Riley, 1998). According to Aaker's (1991) concept of brand equity, slogans are an element of the brand identity, besides the brand name and logo (Kohli et al., 2007). On corporate identity and corporate communications. brand name, logos and slogans might act as one (Anwar, 2015). Brand name gives to the product its core identity and logos serve as visual cues for processing brand recognition. In addition, slogans might also be important in branding (Miller \& Toman, 2014 and 2015) with a supplemental role to brand names and logos, since they might contribute to the brand equity, improving its awareness, image and positive associations (Dahlén \& Rosengren, 2005).

So, it is possible to conclude that a slogan might contribute to build or reinforce the image, identity or position for a brand by trying to increase its memorability (O'guinn et al., 2011). Assuming this role in building or reinforcing the brand image, a slogan should convey the correct positioning/meaning of the brand and of what makes it distinctive, unique and special.

\subsection{Previous studies on slogans}

It is frequently assumed by managers that slogans contribute positively to brand equity, but few studies have been conducted to test its effects (Rosengren \& Dahlén, 2006). Two types of previous 
studies were found on slogans. The first one is related to the desirable characteristics a slogan should have. These studies are resumed in table 1 and, most of them, are note empirical neither tested. They aim to provide guidelines for creating slogans, based on the knowledge of the authors. Bauerly and Tripp (1997) add that it is much more difficult to create a slogan than to enunciate the desirable characteristics of them.

Table 1. Previous studies on creating slogans

\begin{tabular}{|c|c|}
\hline Authors & Guidelines for slogans \\
\hline Molian (1993) & $\begin{array}{l}\text { According to advertising decision-makers, an effective slogan should be: } \\
\text { - easy to remember } \\
\text { - make a distinctive claim } \\
\text { - easily understood } \\
\text { - highlight a customer benefit } \\
\text { - convey a sense of mission } \\
\text { - credible }\end{array}$ \\
\hline Harris \& Attour (2003) & $\begin{array}{l}\text { When managing international brands, companies should decide on which slogan practice } \\
\text { to adopt in each country: } \\
\text { - same language/different meaning } \\
\text { - translated/same meaning } \\
\text { - completely different meaning }\end{array}$ \\
\hline Rosengren \& Dahlén (2005) & $\begin{array}{l}\text { Repetition of slogans is important, since consumers frequently are unable to match a } \\
\text { slogan with its sponsor/advertising brand }\end{array}$ \\
\hline Kohli et al. (2007) & $\begin{array}{l}\text { A slogan should: } \\
\text { - include the future of the business } \\
\text { - position the brand in a clear way } \\
\text { - link the slogan to the brand } \\
\text { - be absolutely consistent from ad-to-ad and be repeated } \\
\text { - be used at the outset } \\
\text { - be creative }\end{array}$ \\
\hline Stewart \& Clark (2007) & $\begin{array}{l}\text { Slogans are most effective when are geared toward a specific audience. } \\
\text { A slogan must connect with the public in two areas: } \\
\text { - be understood by the consumer } \\
\text { - be readily associated to the brand it represent }\end{array}$ \\
\hline Abdi \& Irandoust (2013) & $\begin{array}{l}\text { Basic principles in designing effective advertising slogans: } \\
\text { - advertising slogans should be subject to the future coming business } \\
\text { - the slogan should position the brand carefully and clearly } \\
\text { - yoke the brand with slogan, use the slogan from the start and repeat it } \\
\text { - a creative slogan and/or use of jingles are effective }\end{array}$ \\
\hline
\end{tabular}

Another type of studies is the one related to the effects of slogans in consumers (e.g. Laran et al., 2010). In this type of studies, Dahlén and Rosengren (2005) found that slogans might be carriers of brand equity. Ennis and Zanna (1993) found that slogans affect product beliefs about the product (cars). Boush (1993) concluded that brand slogans seem to influence the acceptability of potential brand extensions and that there are significant relationships between the theme of a slogan and the categories of product it can be applied. Boush (1993) and Pryor and Brodie (1998) findings are that slogans can either support or undermine a brand extension strategy, by drawing attention to attributes that the new product has in common or in conflict with the existing ones. Fransen et al. (2007) study adds that slogans frequently try to associate brands with personal dreams and ambitions, exerting benefits to consumers, since purchasing those brands might help the consumer in achieving and expressing ideals and aspirations.

Also in this type of studies, concerning the recall of slogans, Rosengren and Dahlén (2006) concluded that, in mature brands, the key of effective slogans is to be noticed, not to be liked, and, therefore, it is important to find ways to ensure sufficient processing of the brand-slogan link. Dahlén 
and Rosengren (2005) found that slogan learning was biased by the brand equity and, consequently, slogans of stronger brands were normally better favored. Katz and Rose (1969) found that slogan familiarity increases with age for some products and decreases for other products. Those authors also found that familiarity with slogans increases with consumption. Reece et al. (1994) concluded that the figure of linguistic devices (amount and type of wordplay) in a slogan has a significant positive effect on correct identification rates. Bradley and Meeds (2002) results indicated that syntactic complexity did not influence the comprehension of advertising slogans. Reece et al. (1994) found that younger participants had better recall ability and men had also better recall ability, which is contradictory with Katz and Rose (1969) results.

Katz and Rose (1969) also found that there is a significant incorrect recall for slogans, especially in heavily advertised markets with products lacking differentiation. Rosengren and Dahlén (2006) mention that mismatching of slogans and brands can be explained by the different memory processes utilized by individuals, and the study of Dimofte and Yalch (2007) pointed that the unconscious impact of polysemous brand slogans might be more influential than intuitively expected. Those authors also found that individuals with high automatic access had stronger implicit connections between the advertised brand and the negative feature involved in the secondary meaning than the individuals with low automatic access. Yalch (1991) report that there are conditions when advertising slogans enhances memory and conditions when it does not. The author found that memory for advertising slogans was improved when the slogans were integrated into the advertisement in the form of a jingle/song. Stewart and Clark (2007) found slogans are most effective when they are geared toward a specific audience.

Analysing the frameworks of the studies, the most used dependent variable has been slogan familiarity or correct/incorrect recall (Bauerly \& Tripp, 1997). Only few studies used other dependent variables, like slogan appreciation (e.g. Lagerwerf, 2002). The majority of the studies used extrinsic elements (e.g. age, gender, consumption rate) as independent variables to explain the slogan recall or recognition, not considering slogan intrinsic characteristics. Some of the studies found report contradictory findings - some studies conclude that demographic variables (e.g. age and gender) have a positive correlation with the slogan effectiveness, but other studies did not find it significant.

Summarizing, in a global analysis the literature review points out that slogans are important in branding and advertising. The literature review also indicates guidelines on how to create slogans, although few scientific empirical studies were found in order to test if those guidelines are adequate.

\section{Research Questions}

The general research question established in this study was: "which factors most affect the effectiveness of slogans, considering their recall and recognition?". The results and findings of the present study intend to contribute to a more effective creation and management of slogans, in the context of branding management and advertising. 
http://dx.doi.org/10.15405/epsbs.2016.11.02.29

eISSN: 2357-1330 / Corresponding Author: Paulo Duarte Silveira

Selection and peer-review under responsibility of the Organizing Committee of the conference

To evaluate the effectiveness of slogans, the recall and recognition were used as dependent variables, because the prominence of activation of a brand in memory has been linked to brand choice, since it makes the associations about the brand more salient and, consequently, the brand has a higher chance to be included in the evoked and consideration set (Vieceli \& Shaw, 2010). Besides that, Rosengren and Dahlén (2006) mention that recall and recognition are main elements of memorability commonly employed to evaluate brand awareness.

According to Kumar (2000), it is expected that consumers recall less than $25 \%$ of the advertising they are exposed to on a day. This led us to test Kumar's (2000) threshold of $25 \%$, applied to the recall of slogans, as being $\mathrm{Ha}$ ) Individuals recall less than $25 \%$ of slogans.

Since brands exist in a cluttered environment competing with other stimulus for the attention of individuals (Rosengren \& Dahlén, 2006), the coherence and repetition of the brand messages are important in creating and establishing the brand positioning. Therefore, they should be managed in a long-term perspective, as well as slogans. According to that, a second hypothesis was stated as $H b$ ) The most senior slogans have higher recall rates than the most recent ones (H0: $\rho=0)$.

From the slogan definition results one of its desirable characteristics - to be short. Besides that, since the cognitive processing capacity is a limited resource, simple-syntax words and shorter words might have a higher correct recall (Bradley \& Meeds, 2002). Corder (1986) also identified the importance of shorter slogans in the learning process. Based on those facts, it was established $H c$ ) The shorter slogans have higher recall rates than the more lengthy ones (HO: $\rho=0)$.

According to Katz and Rose (1969), the significant incorrect recall of slogans and advertising in heavily advertised markets can be explained by the industry/product category they belong to. This fact was the basis to formulate $H d$ ) There is no significant difference between the recall of slogans from different industries.

Fuertes-Olivera et al. (2001) and Harris and Attour (2003) mention that, in some cases, the slogans are translated and, in other cases, they are not. Due to that, in the present study it was also tested if $\mathrm{He}$ ) There is no significant difference between the recall of slogans between the language they are communicated.

Rice and Bennett (1998) refer that individuals are more likely to pay attention and process information related to brands they like. So, the engagement with the brand might be a possible explanation for different levels of slogan recall, considering the tendency of consumers to include important brands as part of their self-concepts (Sprott et al., 2009). This means that brand usage and brand love might influence the slogan recall/recognition. According to these, $\mathrm{Hg}$ ) and $\mathrm{Hi}$ ) were formulated as $\mathrm{Hg}$ ) Brands with higher consuming frequency have higher slogan recall rates and $\mathrm{Hi}$ ) Brands with higher consumer sympathy have higher slogan recall rates. 


\section{Research Methods}

To suit the research questions, an empirical quantitative study was implemented, via administration of an original self-administrated questionnaire, applied face-to-face.

The sample constituted of 156 undergraduate business and marketing students, considering a convenience sampling technique.

The dependent variables measured were the recall and recognition rates of twenty one brand slogans, from nine business-to-consumer product categories: retailing, cokes, juices, water, sports, telecoms (mobiles), beer, personal care and ice-cream. In each product category, the leading brands (leader and challengers) were studied, due to their high and recent mass media advertising investments and exposures. A descriptive summary of the twenty one slogans/brands included in the study is presented in table 2 .

Taking in consideration the literature review, the independent variables used were: slogan antiqueness, slogan length, slogan language, product category, brand consuming frequency and sympathy towards the brand.

Table 2. Summary of brand profiles

\begin{tabular}{|c|c|c|c|c|}
\hline Product Category & Brand Code & Brand & Brand Nationality & Slogan Language \\
\hline \multirow[t]{4}{*}{ Retailing } & A & Continente & national & national * \\
\hline & B & Auchan/Jumbo & international & national * \\
\hline & $\mathrm{C}$ & Pingo Doce & national & national * \\
\hline & $\mathrm{D}$ & Lidl & international & national * \\
\hline \multirow[t]{2}{*}{ Soft drinks - Cokes } & $\mathrm{E}$ & Coke & international & translated* - same meaning \\
\hline & $\mathrm{F}$ & Pepsi & international & translated* - same meaning \\
\hline \multirow[t]{2}{*}{ Soft Drinks - Juices } & G & Compal & national & national * \\
\hline & $\mathrm{H}$ & Sumol & national & national * \\
\hline \multirow[t]{2}{*}{ Water } & I & Luso & national & national * \\
\hline & $\mathrm{J}$ & Vitalis & national & national * \\
\hline \multirow[t]{2}{*}{ Sports } & $\mathrm{K}$ & Nike & international & not translated - English \\
\hline & $\mathrm{L}$ & Adidas & international & not translated - English \\
\hline \multirow[t]{3}{*}{ Telecoms (mobiles) } & M & Tmn (today is Meo) & national & national $*$ \\
\hline & $\mathrm{N}$ & Vodafone & international & not translated - English \\
\hline & $\mathrm{O}$ & Optimus (today is Nos) & national & national * \\
\hline \multirow[t]{2}{*}{ Beer } & $\mathrm{P}$ & Sagres & national & national * \\
\hline & Q & Super-Bock & national & national * \\
\hline \multirow[t]{2}{*}{ Personal care } & $\mathrm{R}$ & Gillette & international & translated* - same meaning \\
\hline & $\mathrm{S}$ & L’Óreal & international & translated* - same meaning \\
\hline \multirow[t]{2}{*}{ Ice-cream } & $\mathrm{T}$ & Olá & international & translated* - same meaning \\
\hline & $\mathrm{U}$ & Nestlé & international & translated* - same meaning \\
\hline
\end{tabular}

* language: Portuguese

As noted before, the dependent variables were slogan recall and recognition. These variables were operationalized measuring the spontaneous/non-aided recall of each slogan and the aided/assisted 
recognition of the slogan. To do so, cues were provided, since they are an effective and common way to measure the salience of a product/brand (Alba \& Chattopadhyay, 1986). The cue used to measure the spontaneous/non-aided recall was the name of each brand. To measure the aided recognition, three slogan alternatives were provided for each brand: the actual slogan, an older slogan and a mix of them.

The independent variables were operationalized as:

- slogan antiqueness: after gathering information of the launch date for each slogan, three ordinal categories were established : less than one year; between one year and four years; five years or more (Table 3);

- slogan length: the number of characters (including spaces) in each slogan was counted, reflecting a quantitative ratio variable (Table 3);

- slogan language: each slogan was coded into one of three nominal categories - not translated (national), translated with the same meaning of the original slogan or translated with a different meaning from the original slogan (Table 2);

- product category: simple nominal identification of the main product category for each brand;

- brand consuming frequency: simple item ordinal categorization (very frequent consuming/user; moderate consuming/user; less consuming/user), using Diamantopoulos et al. (2012) indications;

- sympathy towards the brand: simple item ordinal categorization ("have sympathy towards the brand"; "the brand is indifferent"; "have antipathy towards the brand"), using Diamantopoulos et al. (2012) indications.

Table 3. Slogans intrinsic characteristics

\begin{tabular}{|c|c|c|c|c|}
\hline Product Category & Brand & $\begin{array}{l}\text { Slogan } \\
\text { Antiqueness* }\end{array}$ & $\begin{array}{l}\text { \# Words in } \\
\text { Slogan }\end{array}$ & $\begin{array}{l}\text { \# Characters in } \\
\text { Slogan }\end{array}$ \\
\hline \multirow[t]{4}{*}{ Retailing } & Continente & Lower & 7 & 38 \\
\hline & Auchan/Jumbo & Medium & 3 & 18 \\
\hline & Pingo Doce & Medium & 5 & 24 \\
\hline & Lidl & Medium & 5 & 25 \\
\hline \multirow[t]{2}{*}{ Cokes } & Coke & Lower & 4 & 27 \\
\hline & Pepsi & Medium & 4 & 20 \\
\hline \multirow[t]{2}{*}{ Juices } & Compal & Higher & 4 & 23 \\
\hline & Sumol & Medium & 2 & 18 \\
\hline \multirow[t]{2}{*}{ Water } & Luso & Medium & 2 & 18 \\
\hline & Vitalis & Medium & 5 & 25 \\
\hline \multirow[t]{2}{*}{ Sports } & Nike & Higher & 3 & 10 \\
\hline & Adidas & Medium & 4 & 16 \\
\hline \multirow[t]{3}{*}{ Telecoms (mobiles) } & Tmn & Higher & 2 & 6 \\
\hline & Vodafone & Medium & 3 & 13 \\
\hline & Optimus & Medium & 5 & 23 \\
\hline \multirow[t]{2}{*}{ Beer } & Sagres & Lower & 2 & 9 \\
\hline & Super-Bock & Higher & 2 & 15 \\
\hline \multirow[t]{2}{*}{ Personal care } & Gillette & Higher & 5 & 21 \\
\hline & L'Óreal & Higher & 3 & 18 \\
\hline \multirow[t]{2}{*}{ Ice-cream } & Olá & Medium & 2 & 19 \\
\hline & Nestlé & Medium & 3 & 15 \\
\hline
\end{tabular}




\section{Findings}

According to Stewart and Clark (2007), a slogan should be readily associated with the brand it represents, which led us to calculate the spontaneous recall rate and assisted recognition rate for each slogan. The assisted recognition rate was coded in two categories - "correct" or "incorrect slogan".

The spontaneous recall was analysed coding the open responses in six mutually exclusive categories. The responses with a correct indication of the slogan were divided in (results presented in table 4):

- totally correct slogan (the actual slogan for that brand was written);

- partially correct slogan (at least 50\% correct words);

On the other hand, some respondents did not indicate any slogan for the brand, but others responded with an incorrect indication of the slogan. Those responses were coded in (results presented in table 5):

a) incorrect slogan, because it was written the jingle

b) incorrect slogan, because it was written an older version of the slogan

c) incorrect slogan, due to other factors

The associated results of the spontaneous recall and assisted recognition rates of slogans presented in table 4 and table 5 demonstrate a clear and high variation among the brands studied. In fact, the highest recall/spontaneous rate was $65 \%$ and the minimum was $0 \%$. The maximum recognition/assisted rate found was $94 \%$ and the minimum was $10 \%$. In table 4 it is clear that the mean of all the spontaneous recall rates was not high (15\%) and only two brands had spontaneous recognition rates higher than $50 \%$ ("Nike" and "Tmn"). With no surprise, the stimulation of memory provided an aid for correctly identifying slogans - the mean of all the correct assisted recognition rates is higher than the spontaneous recall rates (62\% vs $15 \%)$. Associated to this results $H$ a (individuals recall less than $25 \%$ of slogans) was tested and rejected (HO: $\mu=0.25$ vs H1: $\mu<0.25)$, since the highest value for which it would not be rejected is $\mu=0.15(\mathrm{p}=0,240)$.

Table 4. Correct recall and recognition of slogans

\begin{tabular}{|c|c|c|c|c|}
\hline \multirow[b]{2}{*}{ Product Category } & \multirow[b]{2}{*}{ Brand } & \multicolumn{2}{|c|}{ Spontaneous Recall (\%) } & \multirow{2}{*}{$\begin{array}{l}\text { Assisted Recognition (\%) } \\
\text { correct }\end{array}$} \\
\hline & & i) totally correct & ii) partially correct & \\
\hline \multirow[t]{5}{*}{ Retail stores } & Continente & $4 \%$ & $21 \%$ & $85 \%$ \\
\hline & Auchan/Jumbo & $8 \%$ & $0 \%$ & $74 \%$ \\
\hline & Pingo Doce & $37 \%$ & $3 \%$ & $55 \%$ \\
\hline & Lidl & $13 \%$ & $5 \%$ & $80 \%$ \\
\hline & Retail Stores industry mean & $16 \%$ & $7 \%$ & $74 \%$ \\
\hline \multirow[t]{3}{*}{ Soft drink - Cokes } & Coke & $2 \%$ & $4 \%$ & $30 \%$ \\
\hline & Pepsi & $0 \%$ & $0 \%$ & $60 \%$ \\
\hline & Soft.D.Coke industry mean & $1 \%$ & $2 \%$ & $45 \%$ \\
\hline \multirow[t]{3}{*}{ Soft drink - Juices } & Compal & $1 \%$ & $6 \%$ & $26 \%$ \\
\hline & Sumol & $18 \%$ & $7 \%$ & $71 \%$ \\
\hline & Soft D.Juices industry mean & $10 \%$ & $7 \%$ & $49 \%$ \\
\hline \multirow[t]{3}{*}{ Water } & Luso & $0 \%$ & $0 \%$ & $10 \%$ \\
\hline & Vitalis & $1 \%$ & $0 \%$ & $66 \%$ \\
\hline & Water industry mean & $1 \%$ & $0 \%$ & $38 \%$ \\
\hline \multirow[t]{3}{*}{ Sports apparel } & Nike & $61 \%$ & $1 \%$ & $94 \%$ \\
\hline & Adidas & $0 \%$ & $0 \%$ & $15 \%$ \\
\hline & Sports. Appar. industry mean & $31 \%$ & $1 \%$ & $55 \%$ \\
\hline Telecoms & Tmn & $65 \%$ & $0 \%$ & $94 \%$ \\
\hline
\end{tabular}


http://dx.doi.org/10.15405/epsbs.2016.11.02.29

eISSN: 2357-1330 / Corresponding Author: Paulo Duarte Silveira

Selection and peer-review under responsibility of the Organizing Committee of the conference

\begin{tabular}{lllll} 
(mobiles) & Vodafone & $15 \%$ & $1 \%$ & $77 \%$ \\
& Optimus & $15 \%$ & $1 \%$ & $71 \%$ \\
\multirow{3}{*}{ Beer } & Telecoms industry mean & $32 \%$ & $1 \%$ & $81 \%$ \\
& Sagres & $5 \%$ & $0 \%$ & $63 \%$ \\
\multirow{3}{*}{ Personal care } & Super-Bock & $18 \%$ & $0 \%$ & $97 \%$ \\
& Beer industry mean & $12 \%$ & $0 \%$ & $80 \%$ \\
& Gillette & $5 \%$ & $1 \%$ & $26 \%$ \\
\multirow{3}{*}{ Ice-cream } & L'Óreal & $31 \%$ & $6 \%$ & $92 \%$ \\
& Persolan Care industry mean & $18 \%$ & $4 \%$ & $59 \%$ \\
& Olá & $6 \%$ & $0 \%$ & $47 \%$ \\
Total Mean & Nestlé & $1 \%$ & $0 \%$ & $65 \%$ \\
\hline
\end{tabular}

A specific case of incorrect indication of slogans was on brand "C" ("Pingo Doce"). In this case (table 5), the jingle was indicated several times (32\%) instead of the slogan. This is coherent with Yalch's (1991) finding that music might act as a mnemonic device in communicating advertising slogans.

Table 5. Incorrect recall and recognition of slogans

\begin{tabular}{|c|c|c|c|c|c|c|}
\hline \multirow[b]{2}{*}{$\begin{array}{l}\text { Product } \\
\text { Category }\end{array}$} & \multirow[b]{2}{*}{ Brand } & \multicolumn{4}{|c|}{ Spontaneous Recall (\%) } & \multirow{2}{*}{$\begin{array}{l}\text { Assisted Recognition } \\
(\%) \\
\text { incorrect }\end{array}$} \\
\hline & & $\begin{array}{l}\text { incorrect } \\
\text { a) }\end{array}$ & $\begin{array}{l}\text { incorrect } \\
\text { b) }\end{array}$ & $\begin{array}{l}\text { incorrect } \\
\text { c) }\end{array}$ & $\begin{array}{l}\text { does not } \\
\text { know }\end{array}$ & \\
\hline \multirow[t]{5}{*}{ Retail stores } & Continente & $0 \%$ & $8 \%$ & $17 \%$ & $50 \%$ & $15 \%$ \\
\hline & Auchan/Jumbo & $0 \%$ & $0 \%$ & $5 \%$ & $87 \%$ & $26 \%$ \\
\hline & Pingo Doce & $32 \%$ & $3 \%$ & $9 \%$ & $16 \%$ & $45 \%$ \\
\hline & Lidl & $0 \%$ & $1 \%$ & $10 \%$ & $72 \%$ & $20 \%$ \\
\hline & $\begin{array}{l}\text { Retail Stores industry } \\
\text { mean }\end{array}$ & $8 \%$ & $3 \%$ & $10 \%$ & $56 \%$ & $26 \%$ \\
\hline \multirow{3}{*}{$\begin{array}{l}\text { Soft drink - } \\
\text { Cokes }\end{array}$} & Coke & $0 \%$ & $9 \%$ & $5 \%$ & $80 \%$ & $70 \%$ \\
\hline & Pepsi & $0 \%$ & $2 \%$ & $1 \%$ & $97 \%$ & $40 \%$ \\
\hline & $\begin{array}{l}\text { Soft.D.Coke industry } \\
\text { mean }\end{array}$ & $0 \%$ & $6 \%$ & $3 \%$ & $89 \%$ & $55 \%$ \\
\hline \multirow{3}{*}{$\begin{array}{l}\text { Soft drink - } \\
\text { Juices }\end{array}$} & Compal & $0 \%$ & $5 \%$ & $17 \%$ & $72 \%$ & $74 \%$ \\
\hline & Sumol & $0 \%$ & $1 \%$ & $3 \%$ & $71 \%$ & $29 \%$ \\
\hline & $\begin{array}{l}\text { Soft D.Juices industry } \\
\text { mean }\end{array}$ & $0 \%$ & $3 \%$ & $10 \%$ & $72 \%$ & $51 \%$ \\
\hline \multirow[t]{3}{*}{ Water } & Luso & $0 \%$ & $8 \%$ & $6 \%$ & $86 \%$ & $90 \%$ \\
\hline & Vitalis & $0 \%$ & $0 \%$ & $4 \%$ & $95 \%$ & $34 \%$ \\
\hline & Water industry mean & $0 \%$ & $4 \%$ & $5 \%$ & $91 \%$ & $62 \%$ \\
\hline \multirow[t]{3}{*}{ Sports apparel } & Nike & $0 \%$ & $0 \%$ & $5 \%$ & $33 \%$ & $6 \%$ \\
\hline & Adidas & $0 \%$ & $8 \%$ & $6 \%$ & $86 \%$ & $85 \%$ \\
\hline & $\begin{array}{l}\text { Sports. Appar. industry } \\
\text { mean }\end{array}$ & $0 \%$ & $4 \%$ & $6 \%$ & $60 \%$ & $45 \%$ \\
\hline \multirow{4}{*}{$\begin{array}{l}\text { Telecoms } \\
\text { (mobiles) }\end{array}$} & Tmn & $0 \%$ & $4 \%$ & $2 \%$ & $29 \%$ & $6 \%$ \\
\hline & Vodafone & $0 \%$ & $15 \%$ & $2 \%$ & $67 \%$ & $23 \%$ \\
\hline & Optimus & $0 \%$ & $7 \%$ & $1 \%$ & $76 \%$ & $29 \%$ \\
\hline & Telecoms industry mean & $0 \%$ & $9 \%$ & $2 \%$ & $57 \%$ & $19 \%$ \\
\hline \multirow[t]{3}{*}{ Beer } & Sagres & $0 \%$ & $1 \%$ & $10 \%$ & $85 \%$ & $37 \%$ \\
\hline & Super-Bock & $0 \%$ & $3 \%$ & $0 \%$ & $80 \%$ & $3 \%$ \\
\hline & Beer industry mean & $0 \%$ & $2 \%$ & $5 \%$ & $83 \%$ & $20 \%$ \\
\hline \multirow[t]{3}{*}{ Personal care } & Gillette & $0 \%$ & $0 \%$ & $3 \%$ & $92 \%$ & $74 \%$ \\
\hline & L’Óreal & $1 \%$ & $0 \%$ & $3 \%$ & $59 \%$ & $8 \%$ \\
\hline & $\begin{array}{l}\text { Persolan Care industry } \\
\text { mean }\end{array}$ & $1 \%$ & $0 \%$ & $3 \%$ & $76 \%$ & $41 \%$ \\
\hline Ice-cream & Olá & $0 \%$ & $1 \%$ & $3 \%$ & $90 \%$ & $53 \%$ \\
\hline
\end{tabular}




\begin{tabular}{|c|c|c|c|c|c|c|}
\hline & Nestlé & $0 \%$ & $0 \%$ & $0 \%$ & $99 \%$ & $35 \%$ \\
\hline & $\begin{array}{l}\text { Ice-cream industry } \\
\text { mean }\end{array}$ & $0 \%$ & $1 \%$ & $2 \%$ & $95 \%$ & $44 \%$ \\
\hline Total Mean & & $2 \%$ & $3 \%$ & $5 \%$ & $72 \%$ & $38 \%$ \\
\hline
\end{tabular}

The testing of $\mathrm{Hb}$ led to the finding that there is a positive relation between the antiqueness of a slogan and its spontaneous correct recall. To deduce it, the antiqueness of each slogan was crosstabulated with its spontaneous recall (using Spearman's $\rho$ ). The null hypothesis (no correlation) was rejected, and a positive moderate correlation is significant from $\alpha=10 \%(\rho=0.396 ; p=0.076)$. So, although there is not a universal case, the older slogans tend to have higher recall rates. In a complementary manner, some of the problems and challenges that a brand might face in repositioning and changing a slogan are illustrated by the fact that some brands (e.g. brands "Continente" and "Adidas") have higher spontaneous recall rates for the older version of their slogans than for the actual version. It seems admissible that Henderson and Cote (1998) findings on modifying logos might as well be applied to modifying slogans, suggesting that the beginning of the process should start with research on the actual company image or the direction the company is moving.

The studying of $H c$ led to its rejection, meaning that shorter slogans have higher correct spontaneous recall than the longer ones. The testing was made correlating the number of characters in each slogan with the respective spontaneous recall rate - the Pearson correlation coefficient obtained was $R=-0.475$. Estimating a linear regression, the R-square obtained was 0,2255 . This correlation is significant at the 0.05 level $(\mathrm{p}=0.03)$.

The analysis of $H d$ provided some evidences that there are significant differences between the spontaneous recall of slogans among different groups of product categories. In fact, it is possible to arrange the industries in different groups, considering the homogeneity of the slogan spontaneous recall rates, as presented in table 6. Although it is possible to arrange the categories in the groups/subsets presented in table 6, it is not evident what (if any) characteristic do categories in each group share.

Table 6. Comparison of means in pairs with Tukey multiple comparison test

\begin{tabular}{|c|c|c|c|c|c|}
\hline \multirow{2}{*}{ Product Category } & \multicolumn{5}{|c|}{ Subset for alpha $=0.05$} \\
\hline & 1 & 2 & 3 & 4 & 5 \\
\hline Water &, 0064 & & & & \\
\hline Soft-drink coke & ,0096 & & & & \\
\hline Ice cream & ,0321 & ,0321 & & & \\
\hline Soft-drink juice & & ,0929 & ,0929 & & \\
\hline Beer & & &, 1122 &, 1122 & \\
\hline Retailing & & &, 1538 & ,1538 & \\
\hline Personal care & & & &, 1763 & \\
\hline Sports apparel & & & & & ,3141 \\
\hline Telecoms & & & & & ,3162 \\
\hline sig. & ,962 &, 121 &, 121 & 083 & 1,000 \\
\hline
\end{tabular}


http://dx.doi.org/10.15405/epsbs.2016.11.02.29

eISSN: 2357-1330 / Corresponding Author: Paulo Duarte Silveira

Selection and peer-review under responsibility of the Organizing Committee of the conference

The testing of He ("there is no significant difference between the recall of slogans between the language they are communicated") revealed no significant differences between the categorical groups of slogans ("national", "not translated - english", "translated - same meaning) $\left(\chi^{2}(4)=11.23 ; p=.21\right)$. This led us to deduce that the language of slogans did not influence its recall rate.

Testing if "brands with higher consuming frequency have higher slogan recall rates" ( $\mathrm{Hg})$, a weak correlation was obtained $(\mathrm{R}=0.17 ; \mathrm{p}=0,07)$. This result means that the consuming frequency does not seem to intensely impact the recall of slogans.

A similar finding is related to the test of "brands with higher consumer sympathy have higher slogan recall rates" (Hi). In fact, a weak positive correlation was also obtained $(\mathrm{R}=0.14 ; \mathrm{p}=0,06)$.

\section{Conclusions}

Managers should consider the high importance of the long term brand positioning, and consequently of the brand slogan longevity, both as being crucial elements to achieve an easily and effective recalled slogan. This result highlights Law's (2002) finding for the need of high binding between memory and brand claims in highly advertised markets.

Besides that, it might also be important to consider the potential benefits of creating short slogans, since they might be easily remembered.

Nevertheless, further studies should be conducted to validate the results found. This study has limitations related to the population analyzed, the industries and brands analyzed and the dimensions and variables measured. From that and from the results found, there are implications for academics, pointing further research directions.

One first research direction is to deepen the analysis if the consumer relationship with the brand affects the recalling of its slogan. In this context, it might be important to explore in what extent does the emotional engagement with the brand affects the recall of its slogan. More specifically, the construct and scales of brand love (Carroll \& Ahuvia, 2006; Batra et al., 2012) and brand affect (Chaudhuri \& Holbrook, 2001) are possible tools. The relationship of the consumer with the brand might also be analyzed according to the brand loyalty concept, in the attitudinal and purchase dimensions referred by Chaudhuri and Holbrook (2001).

A second stream of research to be explored is the development of other complementary measures to evaluate the importance of slogans. Since the measures commonly used are categorical and with a unique item (spontaneous and assisted recall of slogans), it would be useful to develop richer measures, such as multi-item scales to evaluate the recall/recognition of slogans.

A final research topic to be investigated is the related to the gathering of Brand Managers perceptions' about the role of slogans. In this case, assuming that the coherence of the brand 
eISSN: 2357-1330

Selection \& Peer-review under responsibility of the Conference Organization Committee

positioning is relevant (and consequently its slogan), it is useful to discover possible explanations for frequent changes in slogans. In fact, Mathur and Mathur (1995) mention that the desire to improve the financial performance of the firm is a major factor that motivates managers to change slogans, but this is not cross-checked with the effects on the long-term brand positioning.

The results found need also to be validated and tested in other populations, markets, industries and brands.

\section{Acknowledgements}

Authors are grateful and would like to acknowledge the cooperation of the participants in the survey conducted. Authors also acknowledge the collaboration of the colleagues Aníbal Vieira, Graça Penteado and Mário Cravidão, who also contributed to this study with their knowledge.

\section{References}

Aaker, D. (1991). Managing brand equity. New York. The Free Press.

Abdi, S., \& Irandoust, A. (2013). The importance of advertising slogans and their proper designing in brand equity. International Journal of Organizational Leadership, 2(2), 62-69.

Aboulian, L., \& McBride, A. G. (2007). How easy is it to register your slogan?. Journal of Brand Management, 14(4), 359-363.

Alba, J. \& Chattopadhyay, A. (1986). Salience effects in brand recall. Journal of Marketing Research, 23, $363-369$.

Anwar, S. T. (2015). Company slogans, morphological issues, and corporate communications. Corporate Communications: An International Journal, 20(3), 360-374.

Batra, R., Ahuvia, A., Bagozzi, R. (2012). Brand love. Journal of Marketing, 76(2), 1-16.

Bauerly, R. J., \& Tripp, C. (1997). Developing slogans for marketing of higher education. Journal of Marketing for Higher Education, 8(1), 1-14.

Boush, D. (1993). How Advertising Slogans Can Prime Evaluations of Brand Extensions. Psychology \& Marketing, 10(1), 67-78

Bradley, D., Meeds, R. (2002). Surface-structure transformations and advertising slogans: the case of moderate syntactic complexity. Psychology and Marketing, 19(7-8), 595-619.

Carroll, B., Ahuvia, A. (2006). Some antecedents and outcomes of brand love. Marketing Letters, 17(2), 7989.

Caywood, C.\& Gronstedt, A. (2011). When a "selling word" strategy jeopardizes your brand:"the other white meat" as "the other integrated brand strategy. Journal of Integrated Marketing Communications, 38-45.

Chaudhuri, A., Holbrook, M. B. (2001). The chain of effects from brand trust and brand affect to brand performance: the role of brand loyalty. The Journal of Marketing, 81-93.

Corder, C. (1986). Adimpact: A multi-media advertising effectiveness measurement method. Managerial and Decision Economics, 7(4), 243-247.

Dahlén, M., Rosengren, S. (2005). Brands affect slogans affect brands? Competitive interference, brand equity and the brand-slogan link. Journal of Brand Management; 12(3), 151-164.

De Chernatony, L., Riley, F. (1998). Defining a Brand: Beyond The Literature With Experts' Interpretations. Journal of Marketing Management, 14(5), 417-443. 
http://dx.doi.org/10.15405/epsbs.2016.11.02.29

eISSN: 2357-1330 / Corresponding Author: Paulo Duarte Silveira

Selection and peer-review under responsibility of the Organizing Committee of the conference

Denton Jr, R. E. (1980). The rhetorical functions of slogans: Classifications and characteristics. Communication quarterly, 28(2), 10-18.

Diamantopoulos, A., Sarstedt, M., Fuchs, C., Wilczynski, P., \& Kaiser, S. (2012). Guidelines for choosing between multi-item and single-item scales for construct measurement: a predictive validity perspective. Journal of the Academy of Marketing Science, 40(3), 434-449.

Dimofte, C. V., \& Yalch, R. F. (2007). Consumer response to polysemous brand slogans. Journal of Consumer Research, 33(4), 515-522.

Dowling, G. R., \& Kabanoff, B. (1996). Computer-aided content analysis: What do 240 advertising slogans have in common?. Marketing Letters, 7(1), 63-75.

Ennis, R., \& Zanna, M. P. (1993). Attitudes, advertising, and automobiles: A functional approach. Advances in Consumer Research, 20(1), 662-666.

Figueiredo, C. (2005). Redação publicitária. São Paulo. São Paulo.

Fransen, M. L., Fennis, B. M., \& Pruyn, A. T. H. (2007). "Be All You Can Be": The Influence of Advertising Slogans on Regulatory focus and Consumer Spending Behavior. Advances in consumer research, 34, 206-207.

Fuertes-Olivera, P. A., Velasco-Sacristán, M., Arribas-Baño, A., \& Samaniego-Fernández, E. (2001). Persuasion and advertising English: Metadiscourse in slogans and headlines. Journal of Pragmatics, 33(8), 1291-1307.

Harris, G., \& Attour, S. (2003). The international advertising practices of multinational companies: a content analysis study. European Journal of Marketing, 37(1/2), 154-168.

Henderson, P. W., \& Cote, J. A. (1998). Guidelines for selecting or modifying logos. The Journal of Marketing, 14-30.

Katz, M., Rose, J. (1969), Is your slogan identifiable?. Journal of Advertising Research, 9(1), 21-26.

Kohli, C., Leuthesser, L., Suri, R. (2007). Got slogan? Guidelines for creating effective slogans, Business Horizons, 50, 415-422.

Leigh, J. H. (1994). The use of figures of speech in print ad headlines. Journal of Advertising, 17-33.

Lagerwerf, L. (2002). Deliberate ambiguity in slogans: recognition and appreciation. Document design, 3(3), 244-260.

Laran, J., Dalton, A. N., \& Andrade, E. B. (2011). The Curious Case of Behavioral Backlash: Why Brands Produce Priming Effects and Slogans Produce Reverse Priming Effects. Journal of Consumer Research, 37(6), 999-1014.

Law, S. (2002). Can repeating a brand claim lead to memory confusion? The effects of claim similarity and concurrent repetition. Journal of Marketing Research, 39(3), 366-378.

Louro, M., Cunha, P. (2001), Brand Management Paradigms. Journal of Marketing Management, 17(7), 849875.

Mathur, L. K., \& Mathur, I. (1995). The effect of advertising slogan changes on the market values of firms. Journal of Advertising Research, 35(1), 59-59.

McEnally, M. R., \& De Chernatony, L. (1999). The evolving nature of branding: consumer and managerial considerations. Academy of Marketing Science Review, 2(1), 1-16.

Miller, D. W. \& Toman, M. (2014). An analysis of rhetorical figures and other linguistic devices in corporation brand slogans. Journal of Marketing Communications, 1-20,

Miller, D. W., \& Toman, M. (2015). An Analysis of the Syntactic Complexity in Service Corporation Brand Slogans. Services Marketing Quarterly, 36(1), 37-50.

Molian, D. (1993). I am a doughnut': Lessons for the sloganeer. European Business Journal; 5(2); 40-47.

O'guinn, T. C., Allen, C. T., \& Semenik, R. J. (2011). Advertising and integrated brand promotion. SouthWestern Pub. 
eISSN: 2357-1330

Selection \& Peer-review under responsibility of the Conference Organization Committee

Pham, M. T. \& Johar, G. V. (1997), Contingent processes of source identification. Journal of Consumer Research, 24(3), 249-265.

Pryor, K., Brodie, R. (1998), How advertising slogans can prime evaluations of brand extensions: further empirical results. The Journal of Product and Brand Management, 7(6), 497-508.

Reece, B., Vanden Bergh, B., Li, H. (1994). What makes a slogan memorable and who remembers it. Journal of Current Issues \& Research in Advertising, 16(2), 41-57.

Rice, B., \& Bennett, R. (1998). The relationship between brand usage and advertising tracking measurements: International findings. Journal of Advertising Research, 38, 58-66.

Romaniuk, J., \& Sharp, B. (2004). Conceptualizing and measuring brand salience. Marketing Theory, 4(4), 327-342.

Rosengren, S., Dahlén, M. (2006), Brand-Slogan Matching in a Cluttered Environment. Journal of Marketing Communications, 12(4), 263-279

Sprott, D., Czellar, S., \& Spangenberg, E. (2009). The importance of a general measure of brand engagement on market behavior: Development and validation of a scale. Journal of Marketing Research, 46(1), 92104.

Stewart, J. \& Clark, M. (2007), The Effect of Syntactic Complexity, Social Comparison, and Relationship Theory on Advertising Slogan. The Business Review, Summer, 7(1), 113-118.

Supphellen, M., Nygaardsvik, I. (2002), Testing Country Brand Slogans: Conceptual Development and Empirical Illustration of a Simple Normative Model. Journal of Brand Management, 9(4/5), 385-395.

Vakratsas, D., Ambler, T. (1999). How Advertising Works: What Do We Really Know? Journal of Marketing, 63(1), 26-43.

Vieceli, J., Shaw, R. N. (2010). Brand salience for fast-moving consumer goods: an empirically based model. Journal of marketing management, 26(13-14), 1218-1238.

Yalch, R. F. (1991). Memory in a jingle jungle: Music as a mnemonic device in communicating advertising slogans. Journal of Applied Psychology, 76(2), 268. 